UDC $546.19+628.316 .12$

\author{
A.I. Bondarieva, V.Yu. Tobilko, Yu.M. Kholodko, B.Yu. Kornilovych, N.A. Zahorodniuk
}

\title{
EFFICIENT REMOVAL OF ARSENIC(V) FROM WATER USING IRON-CONTAINING NANOCOMPOSITES BASED ON KAOLINITE
}

\author{
National Technical University of Ukraine «Igor Sikorsky Kyiv Polytechnic Institute», Kyiv, Ukraine
}

\begin{abstract}
We studied the main physicochemical features of removing of arsenate from contaminated waters utilizing stabilized nanoscale iron. An inorganic kaolinite matrix was used for stabilization. The structure of adsorbents was studied using some physicochemical methods (X-ray powder diffraction and the low-temperature $\mathrm{N}_{2}$ adsorption-desorption method). It was found that the efficiency of the removal of $\operatorname{arsenic}(\mathrm{V})$ ions depends on the weight ratio of iron nanopowder to kaolinite, whereas it does not depend on the $\mathrm{pH}$ of the water systems in a wide range. Kinetics data were analyzed using pseudo-first-order and pseudosecond-order models. It was stated that the removal of arsenic by iron-containing composites based on kaolinite occurs relatively rapid. The adsorption kinetic was appropriately described by the pseudo-second-order model, indicating the high affinity of arsenates with the surface of the iron-containing nanocomposite. The results demonstrated that the obtained materials have a much higher sorption capacity to $A s(V)$ ions than natural silicates. The Langmuir and Freundlich isotherm equations provided good fittings for the experimental sorption data. It was shown that the sorbents based on stabilized nanoscale iron effectively remove toxic arsenic ions from contaminated water.
\end{abstract}

Keywords: kaolinite, nanoscale zero-valent iron, nanocomposite sorbents, arsenic, water treatment, adsorption.

DOI: $10.32434 / 0321-4095-2022-140-1-11-18$

\section{Introduction}

All living organisms are at risk from arsenic compounds, which are potentially toxic and carcinogenic. Arsenic (As) may enter the human body through both food (seafood, grain and meat) and the respiratory system (inhalation of air contaminated with gaseous waste after burning coal or industrial emissions). However, the most dangerous to human health are inorganic forms of arsenic, which enter the body through drinking water. Chronic exposure to As causes skin lesions, raises the risk of cancer and have a negative impact on the respiratory, nervous, and cardiovascular systems [1,2].

The problem of arsenic content in surface and groundwater is recognized in many countries on all continents and does not depend on the level of their economic development (Bangladesh, India, China, Argentina, Mexico, USA, Hungary, etc.). In some regions, its content in natural bodies of water reaches tens and hundreds of micrograms per $1 \mathrm{dm}^{3}$ [3]. Since the effects of arsenic on the human body are irreversible, only the prevention of its income in drinking water can ensure the preservation of human health. According to the directive documents of the World Health Organization, the permissible concentration of arsenic in drinking water should not exceed $10 \mu \mathrm{g} \mathrm{dm}^{-3}$.

Pollution of groundwater with arsenic is basically caused by natural factors such as geochemical leaching and weathering processes from arsenic rocks $[1,4]$. As for surface waters, potential sources of contamination originate from effluents of industrial plants in non-ferrous extractive metallurgy, pigments, paints and printing industries, and as a result of agricultural activity, etc. $[3,4]$.

In the environment, As exists in several oxidation states $(-3,0,+3,+5)$ that depend on dissolved oxygen concentrations, the redox potential and the $\mathrm{pH}$ of the aqueous system. The most common inorganic forms of As are arsenite forms $\left(\mathrm{H}_{3} \mathrm{AsO}_{3}{ }^{0}\right.$ and $\mathrm{H}_{2} \mathrm{AsO}_{3}{ }^{-}$), which are found in water bodies with anaerobic conditions, and arsenate forms $\left(\mathrm{H}_{2} \mathrm{AsO}_{4}^{-}\right.$ and $\mathrm{HAsO}_{4}{ }^{2-}$ ), which are found in water bodies with oxidizing conditions $[1,4]$. 
In this context, there is a need to develop effective and safe technologies that would ensure the purification of water from arsenic to levels below the maximum contamination level. Various chemical and physicochemical methods are used to purify water from metal ion pollution. However, sorption technologies attract special attention among the recognized methods of water treatment from inorganic toxicants. This is because they enable a high level of heavy metal compounds removal from water [5].

Synthesis of sorbents based on food industry waste, agro-industrial complex waste, and natural raw materials such as zeolites and clays are receiving a lot of attention these days [6,7]. However, the majority of these materials are only efficient for treating natural and wastewater from pollutants that are cationic in nature, such as $\mathrm{Cu}(\mathrm{II}), \mathrm{Zn}(\mathrm{II}), \mathrm{Ni}(\mathrm{II})$, $\mathrm{Co}(\mathrm{II}), \mathrm{Cd}(\mathrm{II}), \mathrm{Pb}(\mathrm{II})[5,7]$.

Thus, the essential challenge is to obtain sorption materials for the efficient removal of inorganic anions (As(III), As(V), $\mathrm{Cr}(\mathrm{VI})$ ) from water. Existent sorbents based on metal oxides and hydroxides (titanium, zirconium, cerium, aluminum and iron) are extremely successful in removing arsenic from water [8], but their major disadvantage is their high cost. Nanopowders based on nanoscale zerovalent metal (nZVM) such as iron, manganese, copper are of interest as an efficient material with high adsorption capacity against inorganic contaminants including arsenic [9]. Powders aggregation, fast oxidation and difficulty in separating nZVM from the treated solution pose substantial challenges to their application in environmental practice. To improve the efficiency of their usage in technological processes, highly reactive nZVM should be stabilized on the surface of organic or inorganic matrices. Activated carbon, silica gel, expanded clay, natural silicates and other materials are commonly used for this purpose [10].

The development of sorbents based on natural clay minerals for water treatment from inorganic pollutants is promising. The structural features of clay minerals allow modifying their surface with various compounds and obtaining new functional materials with unique properties. For example, kaolinite is a common and inexpensive mineral with chemical, mechanical and thermal resistance [11]. In this regard, the relevance of the work is due to the need to develop new highly efficient sorbents based on natural clay mineral for the removal of anionic forms of toxicants from water.

The aim of the research is to study the main physicochemical features of the removal of arsenic
(V) from water using iron-containing nanocomposites based on kaolinite.

\section{Materials and methods}

The natural kaolin, the main rock-forming mineral of which is kaolinite (abbreviated as $\mathrm{K}$ in this study), from the Glukhovets deposit (Ukraine) was the object of this study. Before use, $\mathrm{K}$ was purified from impurities of quartz, feldspars, carbonates and other minerals by a sedimented method. The ironcontaining nanocomposites $\left(\mathrm{Fe}^{0}-\mathrm{K}\right)$ was prepared following the methodology described elsewhere [12]. The kaolinite was first dissolved into deionized water and then, under stirring, added to iron (III) chloride hexahydrate solution with a certain concentration. The next dropwise addition of a solution of sodium borohydride $\mathrm{NaBH}_{4}$ to a suspension of kaolinite for one hour resulted in a reduction of $\mathrm{Fe}^{3+}$ ions. The reduction reaction is represented as follows:

$$
\begin{aligned}
& 4 \mathrm{Fe}^{3+}+3 \mathrm{BH}_{4}^{-}+9 \mathrm{H}_{2} \mathrm{O} \rightarrow \\
& \rightarrow 4 \mathrm{Fe}^{0}+3 \mathrm{H}_{2} \mathrm{BO}_{3}^{-}+6 \mathrm{H}_{2} \uparrow+12 \mathrm{H}^{+} .
\end{aligned}
$$

After that, the obtained black suspension was stirred for another 1 hour to complete the redox reaction. The solid phase was then separated from the liquid phase by centrifugation. The samples were washed several times with ethyl alcohol and dried under a vacuum at a temperature of $60^{\circ} \mathrm{C}$. The resulting precipitate was crushed and sieved to obtain a fraction $\leq 0.2 \mathrm{~mm}$. As a result, we obtained 4 sorbents with different mass ratios of $\mathrm{Fe}^{0}: \mathrm{K}: 0.01: 1$; $0.05: 1 ; 0.1: 1$ and 0.2:1.

Figure 1 shows a photo of the obtained sorbents, which demonstrates that their color varies depending on the amount of iron applied to the kaolinite surface. Moreover, the bigger $\mathrm{Fe}^{0}$, the blacker is the sample.

The efficacy of sorbent materials was evaluated using arsenic(V)-containing model solutions. An arsenic standard solution with a concentration of $1000 \mathrm{mg} \mathrm{dm}^{-3}$ was used to this end. The ionic strength $(\mathrm{I}=0.01)$ was maintained using a $1 \mathrm{M} \mathrm{NaCl}$ solution.

To control the monomineralic character of $\mathrm{K}$ and determine the phase composition of the obtained iron-containing nanocomposites, X-ray powder diffraction (XRD) patterns were recorded on DRON-4-07 diffractometer in the range of 2 to $60^{\circ}$ (20) using $\mathrm{CuK}_{\alpha}$ radiation.

The parameters of the porous structure were determined on evacuated samples by the lowtemperature $\mathrm{N}_{2}$ adsorption-desorption method $\left(\mathrm{T}=-196^{\circ} \mathrm{C}\right)(\mathrm{Quantachrome}$ NOVA-2200e Surface Area and Pore Size Analyzer, USA). The results were processed using the ASiQwin ${ }^{\mathrm{TM}}$ V 3.0 software. The 

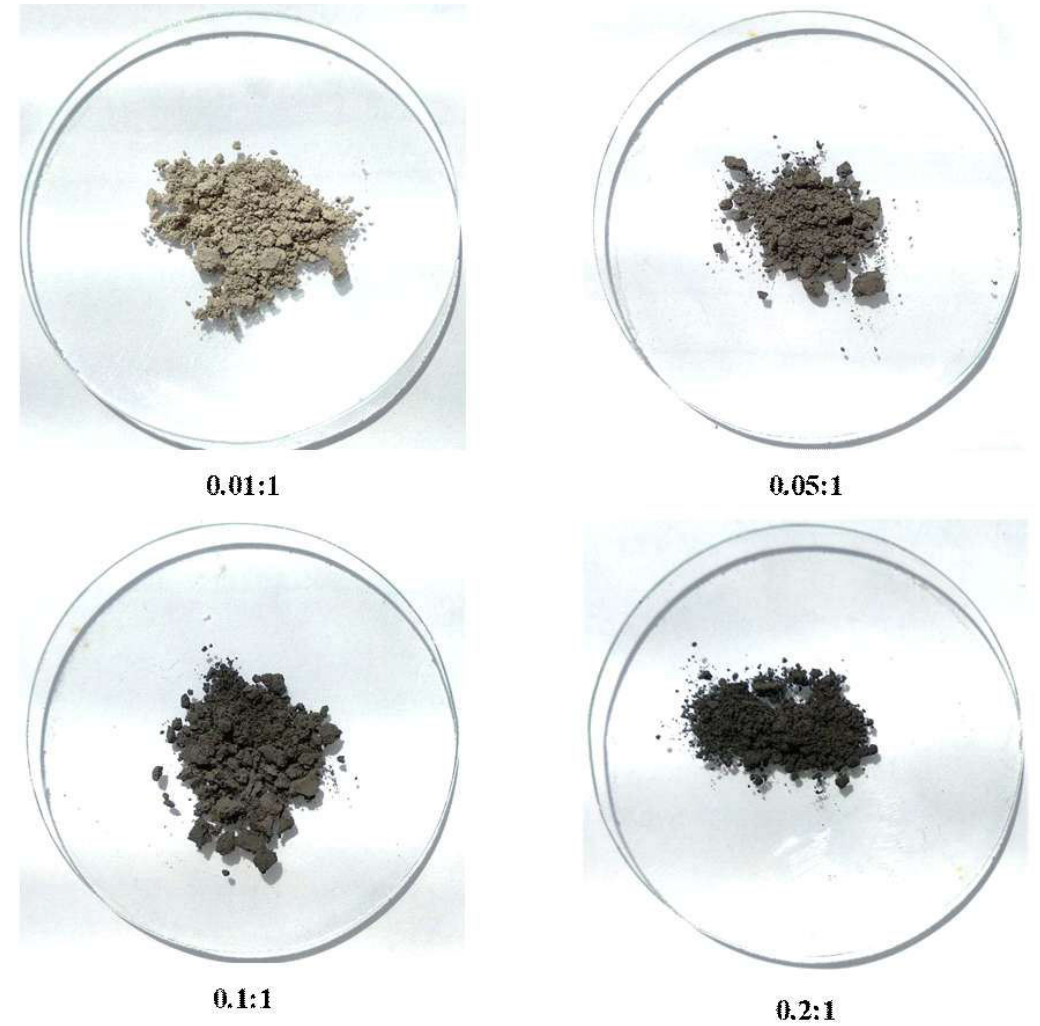

Fig. 1. Synthesized sorbents with different mass ratio $\mathrm{Fe}^{0}: \mathrm{K}$

specific surface area $\left(\mathrm{S}_{\mathrm{BET}}, \mathrm{m}^{2} \mathrm{~g}^{-1}\right)$ was measured by multipoint BET method (Brunauer-Emmett-Teller). The total pore volume $\left(\mathrm{V}_{\Sigma}, \mathrm{cm}^{3} \mathrm{~g}^{-1}\right)$ was calculated using the maximum adsorbed volume of nitrogen at a relative pressure $\mathrm{p} / \mathrm{p}_{0} \approx 0.99$. The volume of micropores $\left(\mathrm{V}_{\mu}, \mathrm{cm}^{3} \mathrm{~g}^{-1}\right)$ was determined by the $\mathrm{t}$-plot method, and their percentage was calculated using the following formula:

$$
\mathrm{V}_{\mu}, \%=\left(\mathrm{V}_{\mu} / \mathrm{V}_{\Sigma}\right) \cdot 100 \% \text {. }
$$

The efficiency of removing arsenic from water by using the obtained nanocomposites is dependent on many factors, including the mass ratio of $\mathrm{Fe}^{0}$ to $\mathrm{K}$, the sorbent dose, the $\mathrm{pH}$ of the water, the time of sorption equilibrium, and the initial concentration of $\mathrm{As}(\mathrm{V})$ in solution. All experiments were conducted by adding $0.1 \mathrm{~g}$ adsorbent to $50 \mathrm{~cm}^{3}$ arsenic solutions.

To establish the optimal mass ratio of $\mathrm{Fe}^{0}: \mathrm{K}$, which provides the maximum removal efficiency arsenic from water, we used a solution of $\mathrm{As}(\mathrm{V})$ with the concentration of $6 \mathrm{mg} \mathrm{dm}^{-3}$ at $\mathrm{pH}=6.0$.

In order to investigate the effect of $\mathrm{pH}$ on adsorption, the initial $\mathrm{pH}$ was varied from 3 to 8 . The $\mathrm{pH}$ of the solutions was adjusted with $0.1 \mathrm{M}$ solution $\mathrm{NaOH}$ and initial concentration of $\mathrm{As}(\mathrm{V})$ was $6 \mathrm{mg} \mathrm{dm}^{-3}$.
In the kinetic study, the initial model solutions with the concentration of $6 \mathrm{mg} \mathrm{dm}^{-3}$ were stirred at different time intervals (10-240 min) in an orbital shaker at $190 \mathrm{rpm}$ and the temperature of $20 \pm 2^{\circ} \mathrm{C}$. Pseudo-first-order (PFO) and pseudo-second-order (PSO) models were used to describe the kinetic experimental results. The PFO and PSO rate equations can be respectively written as follows:

$\ln \left(\mathrm{q}_{\mathrm{e}}-\mathrm{q}_{\mathrm{t}}\right)=\ln \mathrm{q}_{\mathrm{e}}-\mathrm{k}_{1} \mathrm{t}$,

$\frac{\mathrm{t}}{\mathrm{q}_{\mathrm{t}}}=\frac{1}{\mathrm{k}_{2} \mathrm{q}_{\mathrm{e}}^{2}}+\frac{\mathrm{t}}{\mathrm{q}_{\mathrm{e}}}$,

where $\mathrm{q}_{\mathrm{e}}$ and $\mathrm{q}_{\mathrm{t}}\left(\mathrm{mg} \mathrm{g}^{-1}\right)$ are the adsorption capacity at equilibrium and at any time ( $\mathrm{min})$, respectively; $\mathrm{k}_{1}\left(\mathrm{~min}^{-1}\right)$ and $\mathrm{k}_{2}\left(\mathrm{~g} \mathrm{mg}^{-1} \mathrm{~min}^{-1}\right)$ are the PFO and PSO rate constant, respectively.

The adsorption experiments were performed in the range of initial concentrations of $0.5-20 \mathrm{mg} \mathrm{dm}^{-3}$ under static conditions at room temperature $\left(20 \pm 2^{\circ} \mathrm{C}\right)$ and the ratio of solid and liquid phases $\mathrm{S}: \mathrm{L}=1: 500$. The residual $\mathrm{As}(\mathrm{V})$ concentrations were determined by the inductively coupled plasma atomic emission spectroscopy (Thermo Scientific iCAP 7400 ICP-OES, USA). 
The Langmuir (Eq. (4)) and Freundlich (Eq. (5)) isotherm equations were used to describe the experimental adsorption data of $\mathrm{As}(\mathrm{V})$ on the $\mathrm{Fe}^{0}-\mathrm{K}$ :

$\mathrm{q}_{\mathrm{e}}=\frac{\mathrm{q}_{\max } \mathrm{K}_{\mathrm{L}} \mathrm{C}_{\mathrm{e}}}{1+\mathrm{K}_{\mathrm{L}} \mathrm{C}_{\mathrm{e}}}$,

$\mathrm{q}_{\mathrm{e}}=\mathrm{K}_{\mathrm{F}} \mathrm{C}_{\mathrm{e}}^{1 / \mathrm{n}}$,

where $\mathrm{q}_{\mathrm{e}}\left(\mathrm{mg} \mathrm{g}^{-1}\right)$ is the equilibrium adsorption capacity, $\mathrm{C}_{\mathrm{e}}\left(\mathrm{mg} \mathrm{dm}^{-3}\right)$ denotes equilibrium concentration, $\mathrm{q}_{\max }\left(\mathrm{mg} \mathrm{g}^{-1}\right)$ is the maximum adsorption capacity, $\mathrm{K}_{\mathrm{L}}\left(\mathrm{dm}^{3} \mathrm{mg}^{-1}\right)$ denotes the Langmuir equilibrium constant, and $\mathrm{K}_{\mathrm{F}}\left((\mathrm{mg} / \mathrm{g})\left(\mathrm{dm}^{3} / \mathrm{mg}\right)^{1 / \mathrm{n}}\right)$ and $1 / \mathrm{n}$ are the Freundlich constants related to the adsorption capacity and adsorption intensity, respectively.

The removal efficiency $(\mathrm{X}, \%)$ and adsorption capacity (q, $\mathrm{mg} \mathrm{g}^{-1}$ ) of arsenate ions were estimated by Eq. (6) and Eq. (7), respectively:

$$
\begin{aligned}
& X=\frac{C_{0}-C_{e}}{C_{0}} \cdot 100 \%, \\
& q=\frac{\left(C_{0}-C_{e}\right) \cdot V}{m},
\end{aligned}
$$

where $\mathrm{C}_{0}$ and $\mathrm{C}_{\mathrm{e}}$ are the initial and equilibrium $\mathrm{As}(\mathrm{V})$ concentrations, respectively $\left(\mathrm{mg} \mathrm{dm}^{-3}\right), \mathrm{V}$ is the solution volume $\left(\mathrm{dm}^{3}\right)$, and $\mathrm{m}$ is the weight of adsorbent (g).

\section{Results and discussion}

The X-ray diffraction patterns of $\mathrm{K}$ and $\mathrm{Fe}^{0}-\mathrm{K}$ (0.2:1) are shown in Fig. 2. According to the XRD pattern of K (Fig. 2,a), the diffraction peaks at $2 \theta=12^{\circ}$ $(0.715 \mathrm{~nm}), 20^{\circ}(0.434 \mathrm{~nm}), 25^{\circ}(0.358 \mathrm{~nm})$ and $38^{\circ}$ $(0.238 \mathrm{~nm})$ correspond to the kaolinite phase that agrees with ICDD database PDF File No. 01-078-2110. The presence of characteristic reflections at $2 \theta=21^{0}$ $(0.426 \mathrm{~nm})$ and $27^{\circ}(0.334 \mathrm{~nm})$ confirms the existence of quartz traces (PDF File No. 01-083-2472). The existence of a modifying layer of iron compounds consisting of the crystalline phase $\alpha-\mathrm{Fe}$ at $2 \theta=45^{\circ}$ $(0.198 \mathrm{~nm})$ (PDF File No. 01-076-6588) and small signals of iron oxide $\mathrm{FeO}$ and iron oxyhydroxides $\mathrm{FeOOH}$ on the surface of the iron-containing sample are shown by XRD (Fig. 2,b).

According to the modified de Boer classification, the nitrogen sorption isotherms (Fig. 3) on the investigated materials are of type II (b) isotherms [11]. The shape of the isotherms is typical of non-porous sorbents and indicates that the samples have a mainly macroporous structure, with microand mesopores being practically or entirely absent. The narrow hysteresis loop of type $\mathrm{H} 3$ on isotherms is caused by capillary condensation in kaolinite structural aggregates between weakly linked flat elementary packages of the mineral. Furthermore, narrow hysteresis indicates the presence of fine macropores. The calculated parameters of the samples porous structure are shown in Table 1.

The BET surface area of $\mathrm{Fe}^{0}-\mathrm{K}$ is insignificantly reduced following surface modification $\mathrm{K}$. This decrease is due to the $\mathrm{Fe}^{0}$ aggregation processes of tiny clay particles and almost full closure of

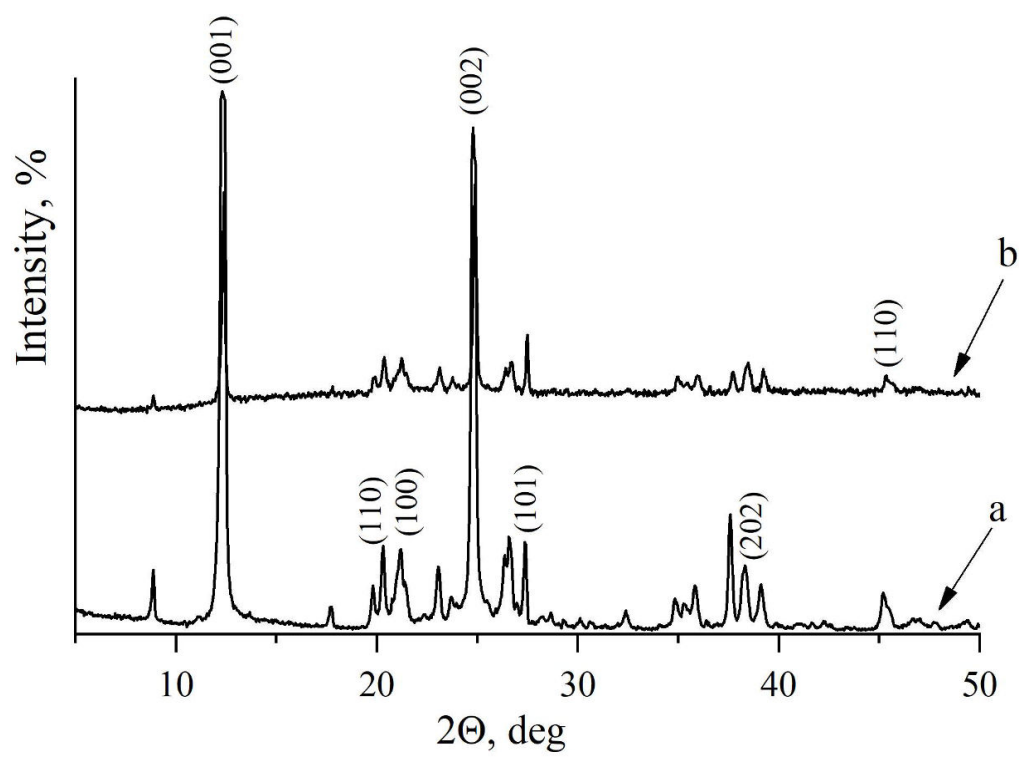

Fig. 2. X-ray powder diffraction patterns of pure (a) and modified (b) kaolinite 


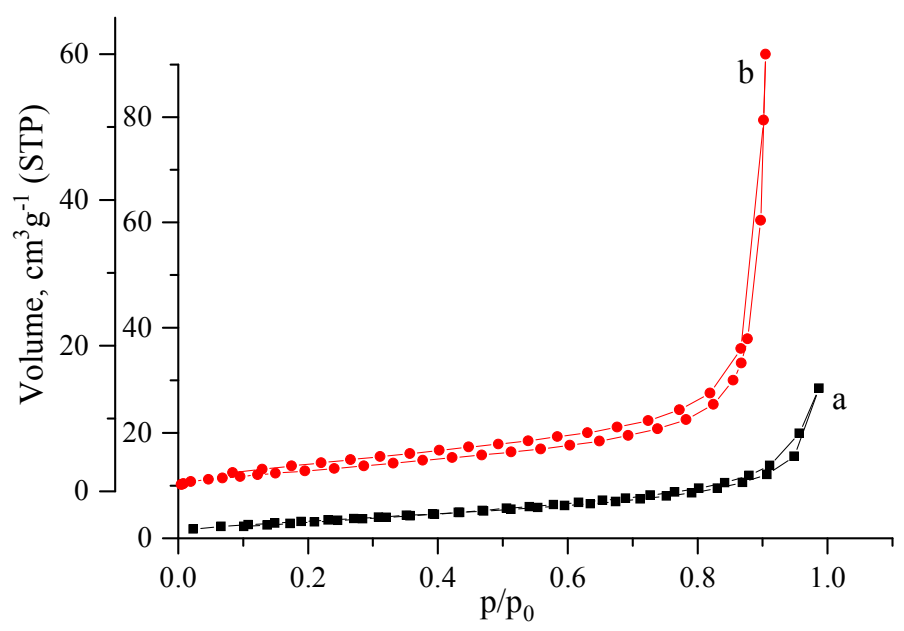

Fig. 3. Adsorption-desorption isotherms of $\mathrm{N}_{2}$ of pure (a) and modified (b) kaolinite

micropores with $\mathrm{Fe}^{0}$ films, resulting in the limited access of nitrogen molecules to these pores.

Table 1

Characteristics of the porous structure of the $K$ and $\mathrm{Fe}^{0}$-K samples (0.2:1)

\begin{tabular}{c|c|c|c|c}
\hline Sample & $\mathrm{S}_{\text {BET }}, \mathrm{m}^{2} \mathrm{~g}^{-1}$ & $\mathrm{~V}_{\Sigma}, \mathrm{cm}^{3} \mathrm{~g}^{-1}$ & $\mathrm{~V}_{\mu}, \mathrm{cm}^{3} \mathrm{~g}^{-1}$ & $\mathrm{~V}_{\mathrm{\mu}}, \%$ \\
\hline $\mathrm{K}$ & 12.84 & 0.0423 & 0.0027 & 6.38 \\
\hline $\mathrm{Fe}^{0}-\mathrm{K}$ & 11.72 & 0.0930 & 0.0029 & 3.12 \\
\hline
\end{tabular}

Figure 4 illustrates the dependence of the removal efficiency from arsenate ions on the amount of $\mathrm{Fe}^{0}$ applied to the surface of kaolinite. According to the findings, an increase in the concentration of nanoscale iron on the surface of kaolinite improves composite adsorption ability. The maximum removal efficiency is $97.74 \%$ for a sample with a mass ration of $\mathrm{Fe}^{0}: \mathrm{K}=0.2: 1$. Thus, this sorbent was chosen for further study.

The obtained experimental data indicate that

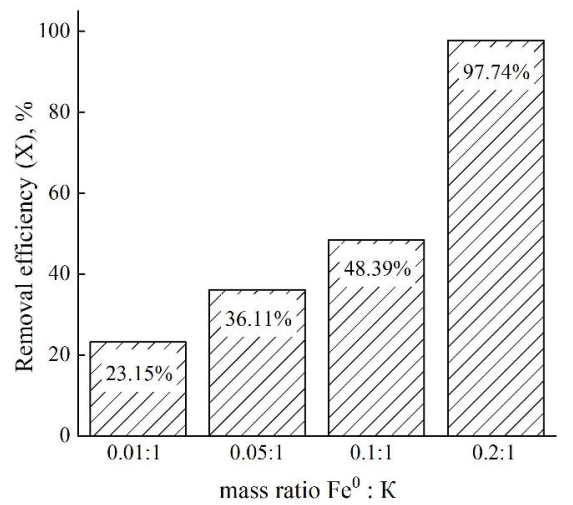

Fig. 4. Diagram of the dependence of the removal efficiency of $\mathrm{As}(\mathrm{V})$ on the content of $\mathrm{Fe}^{0}$ on the surface of kaolinite

the $\mathrm{pH}$ value does not affect the process of As $(\mathrm{V})$ adsorption for $\mathrm{Fe}^{0}-\mathrm{K}$ across a wide range. This is due to the electrostatic interaction between the

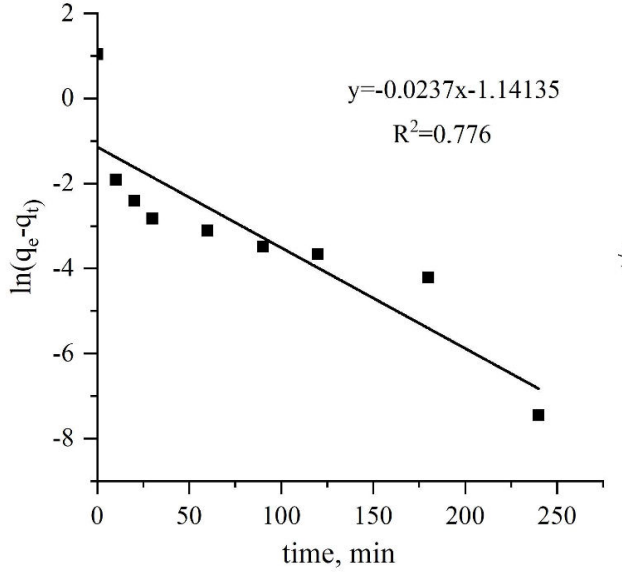

a

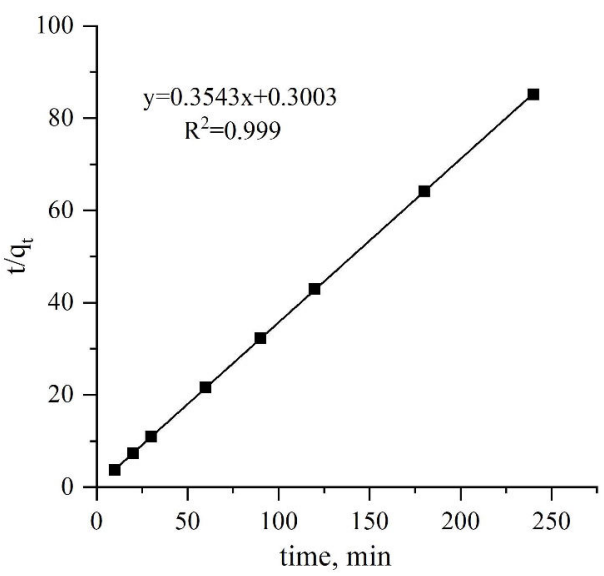

$\mathrm{b}$

Fig. 5. Kinetics of arsenic (V) adsorption on $\mathrm{Fe}^{0}-\mathrm{K}$ composite plotted in the coordinates of the pseudo-first-order model (a) and the pseudo-second-order model (b) 
Kinetic parameters of $\mathrm{As}(\mathrm{V})$ adsorption on $\mathrm{Fe}^{0}-\mathrm{K}\left(\mathrm{C}_{0}=6 \mathrm{mg} \mathrm{dm}^{-3}, \mathrm{~T}=293 \mathrm{~K}, \mathrm{pH}=6.2\right)$

\begin{tabular}{c|c|c|c|c}
\hline Kinetic models & \multicolumn{4}{|c}{ Parameters } \\
\hline \multirow{2}{*}{ Pseudo-first-order } & $\mathrm{q}_{\mathrm{e}, \text { exp }},\left(\mathrm{mg} \mathrm{g}^{-1}\right)$ & $\left.\mathrm{q}_{\mathrm{e}, \text { cal }}, \mathrm{mg} \mathrm{g}^{-1}\right)$ & $\mathrm{k}_{1}, \mathrm{~min}^{-1}$ & $\mathrm{R}^{2}$ \\
\cline { 2 - 5 } & 2.819 & 0.320 & 0.0237 & 0.776 \\
\hline \multirow{2}{*}{ Pseudo-second-order } & $\mathrm{q}_{\mathrm{e}, \text { exp }},\left(\mathrm{mg} \mathrm{g}^{-1}\right)$ & $\mathrm{q}_{\mathrm{e}, \text { call }},\left(\mathrm{mg} \mathrm{g}^{-1}\right)$ & $\mathrm{k}_{2}, \mathrm{~g} \mathrm{mg}^{-1} \mathrm{~min}^{-1}$ & $\mathrm{R}^{2}$ \\
\cline { 2 - 5 } & 2.819 & 2.82 & 0.415 & 0.999 \\
\hline
\end{tabular}

positively charged surface of nanoscale zero-valent iron particles and the negatively charged form of $\mathrm{H}_{2} \mathrm{AsO}_{4}^{-}$in the $\mathrm{pH}$ range of 3-7 [13].

The kinetic experimental data shows a relatively intense rate of $\mathrm{As}(\mathrm{V})$ adsorption on iron-containing nanocomposite based on kaolinite. Rapid adsorption observes during the first $30 \mathrm{~min}$ of contact time. Then, metal adsorption is increasing somewhat until it reached equilibrium. It took around 60 minutes of contact time to get this condition.

PFO and PSO kinetic models of arsenic sorption on $\mathrm{Fe}^{0}-\mathrm{K}$ in the linear forms are shown in Fig. 5. The calculated parameters of the kinetic models are summarized in Table 2.

Analysis of the regression correlation coefficient $\left(\mathrm{R}^{2}\right)$ shows that the kinetic dependence fits the PSO model $\left(\mathrm{R}^{2}>0.99\right)$ better than the PFO model $\left(\mathrm{R}^{2}>0.77\right)$. This indicates a high affinity between arsenate ions and sorbent. Furthermore, the theoretical value of sorption $\left(\mathrm{q}_{\mathrm{e}, \text { cal }}\right)$ at equilibrium is extremely near the experimental value $\left(\mathrm{q}_{\mathrm{e} \text {, exp }}\right)$.

Since the main activity centers of the synthesized material are provided in the form of nanoscale zero-valent iron particles with a «coreshell» structure, the sorption process begins on the surface of the sorbent:

$$
\begin{aligned}
& \equiv \mathrm{FeOH}+\mathrm{H}^{+} \leftrightarrow \equiv \mathrm{FeOH}_{2}^{+} \\
& \equiv \mathrm{FeOH}_{2}^{+}+\mathrm{H}_{2} \mathrm{AsO}_{4}^{-} \leftrightarrow \equiv \mathrm{FeH}_{2} \mathrm{AsO}_{4}+\mathrm{H}_{2} \mathrm{O} \\
& \equiv \mathrm{FeOH}_{2}^{+}+\mathrm{HAsO}_{4}^{2-} \leftrightarrow \equiv \mathrm{FeHAsO}_{4}^{-}+\mathrm{H}_{2} \mathrm{O}
\end{aligned}
$$

After all external sorption centers have been filled with adsorbate, arsenate ions can enter the pores of the material where internal adsorption occurs. As the concentration of $\mathrm{As}(\mathrm{V})$ in the solution diminishes over time, so does the diffusion rate, and an equilibrium condition is attained [14].

Isotherms of sorption of $\mathrm{As}(\mathrm{V})$ on the natural and modified samples of kaolinite at $\mathrm{pH} 6.0$ are shown in Fig. 6. The results demonstrate that the sorbent with the deposited layer of $\mathrm{Fe}^{0}$ has a considerably higher sorption capacity towards arsenate ions than the native material. Thus, the maximum adsorption capacity of arsenate ions on $\mathrm{Fe}^{0}-\mathrm{K}$ is $6.2 \mathrm{mg} \mathrm{g}^{-1}$, whereas it is only $0.1 \mathrm{mg} \mathrm{g}^{-1}$ on $\mathrm{K}$. The calculated coefficients in Langmuir and Freundlich equations are shown in Table 3.

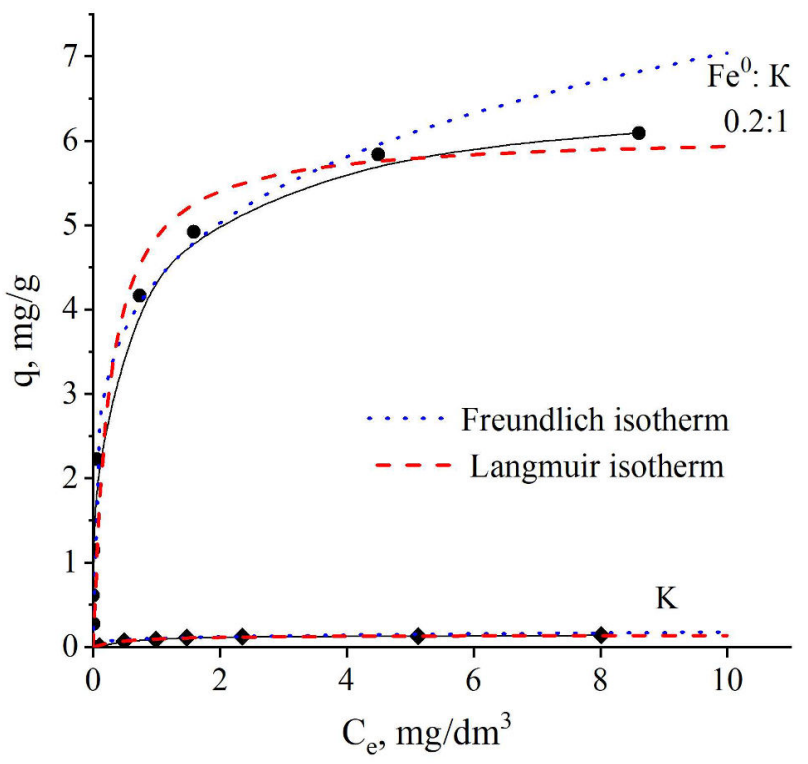

Fig. 6. Sorption isotherms of $\mathrm{As}(\mathrm{V})$ ions on natural kaolinite and iron-containing nanocomposite 
Table 3

Parameters of Langmuir and Freundlich adsorption isotherm equations

\begin{tabular}{c|c|c|c|c|c|c}
\hline \multirow{2}{*}{ Sample } & \multicolumn{3}{|c|}{ Langmuir constants } & \multicolumn{3}{|c}{ Freundlich constants } \\
\cline { 2 - 7 } & $\begin{array}{c}\mathrm{q}_{\max }, \\
\mathrm{mg} \mathrm{g}^{-1}\end{array}$ & $\begin{array}{c}\mathrm{K}_{\mathrm{L},} \\
\mathrm{mg} \mathrm{dm}^{-3}\end{array}$ & $\mathrm{R}^{2}$ & $1 / \mathrm{n}$ & $\mathrm{K}_{\mathrm{F}}$ & $\mathrm{R}^{2}$ \\
\hline $\begin{array}{c}\mathrm{Fe}^{0}-\mathrm{K} \\
(0.2: 1)\end{array}$ & 6.089 & 3.971 & 0.996 & 0.222 & 4.33 & 0.995 \\
\hline $\mathrm{K}$ & 0.143 & 1.970 & 0.998 & 0.268 & 0.090 & 0.916 \\
\hline
\end{tabular}

The obtained data show that the adsorption of As(V) on modified kaolinite is well described by both the Freundlich and Langmuir equations, which is indicated by close to 1 correlation coefficient $\left(\mathrm{R}^{2}>0.99\right)$.

\section{Conclusions}

Iron-containing nanocomposites based on the clay mineral kaolinite were prepared. It was established that the stabilization of nanoscale zerovalent iron on the inorganic matrix avoids aggregation and rapid oxidation of the nanopowder and promotes better separation of the spent sorbent from the liquid phase. It was demonstrated that the produced materials have substantially higher As(V) adsorption capacity than natural kaolinite. It was found that the efficiency of the removal of $\operatorname{arsenic}(\mathrm{V})$ ions depends on the mass ratio of nanopowder of iron and kaolinite. Thus, a sample with a mass ratio of nanoscale zero-valent iron to kaolinite of $0.2: 1$ is the most effective. The $\mathrm{pH}$ of water systems has no effect on the removal effectiveness of arsenate ions by obtained nanocomposite in the $\mathrm{pH}$ range of 3-7. The adsorption kinetic is appropriately described by the pseudo-second-order model. The iron-containing nanocomposites based on kaolinite can be used for the water treatment from arsenic and other anionic toxicants.

\section{REFERENCES}

1. Villaescusa I., Bollinger J.-C. Arsenic in drinking water: sources, occurrence and health effects (a review) // Rev. Environ. Sci. Biotechnol. - 2008. - Vol.7. - P.307-323.

2. Human health effects from chronic arsenic poisoning a review / Kapaj S., Peterson H., Liber K., Bhattacharya P. // J. Environ. Sci. Health. Part A. - 2006. - Vol.41. - No. 10. P.2399-2428.
3. Adeloju S.B., Khan S., Patti A.F. Arsenic contamination of groundwater and its implications for drinking water quality and human health in under-developed countries and remote communities - a review // Appl. Sci. - 2021. - Vol.11. - No. 4. - P. 1926-1950.

4. Arsenic speciation and toxicity in biological systems / Akter K.F., Owens G., Davey D.E., Naidu R. // Rev. Environ. Contam. Toxicol. - 2005. - Vol.184. - P.97-149.

5. Bolisetty S., Peydayesh M., Mezzenga R. Sustainable technologies for water purification from heavy metals: review and analysis // Chem. Soc. Rev. - 2019. - Vol.48. - P.463-487.

6. Comparisons of low-cost adsorbents for treating wastewaters laden with heavy metals / Kurniawan T.A., Chan G.Y., Lo W.H., Babel S. // Sci. Total Environ. - 2006. - Vol.366. P.409-426.

7. Removal of heavy metals from water sources in the developing world using low-cost materials: a review / Joseph L., Jun B.-M., Flora J.R.V., Park C.M., Yoon Y. // Chemosphere. - 2019. - Vol.229. - P.142-159.

8. Technologies for arsenic removal from water: current status and future perspectives / Nicomel N.R., Leus K., Folens K., Voort P., Laing G.D. // Int. J. Environ. Res. Public Health. 2016. - Vol.13. - Art. No.62.

9. Nanoscale zero-valent metals: a review of synthesis, characterization, and applications to environmental remediation / Li L., Hu J., Shi X., Fan M., Luo J., Wei X. // Environ. Sci. Pollut. Res. - 2016. - Vol.23. - P.17880-17900.

10. Environmental remediation and application of nanoscale zero-valent iron and its composites for the removal of heavy metal ions: a review / Zou Y., Wang X., Khan A., Wang P., Liu Y., Alsaedi A., et al. // Environ. Sci. Technol. - 2016. - Vol.50. P.7290-7304.

11. Kuila U., Prasad M. Specific surface area and poresize distribution in clays and shales // Geophys. Prospect. 2013. - Vol.61. - No. 2. - P.341-362.

12. Tobilko V.Yu., Kornilovych B.Yu. Synthesis and sorption properties of composite materials based on nanoscale $\mathrm{Fe}^{0} / /$ East. Eur. J. Enterprise Technol. - 2015. - Vol.4. - No. 5. - P.22-27.

13. The double influence mechanism of $\mathrm{pH}$ on arsenic removal by nano zero valent iron: electrostatic interactions and the corrosion of $\mathrm{Fe}^{0}$ / Wu C., Tu J., Liu W., Zhang J., Chu S., Lu G., et al. // Environ. Sci. Nano. - 2017. - Vol.4. - P.15441552.

14. Montmorillonite-supported nanoscale zero-valent iron for removal of arsenic from aqueous solution: Kinetics and mechanism / Bhowmick S., Chakraborty S., Mondal P., Renterghem W.V., Berghe S.V., Roman-Ross G., et al. // Chem. Eng. J. - 2014. - Vol.243. - P.14-23. 


\section{ЕФЕКТИВНЕ ВИДАЛЕННЯ АРСЕНУ(V) ІЗ ВОДИ 3 ВИКОРИСТАННЯМ ЗАЛІЗОВМІСНИХ НАНОКОМПОЗИТІВ НА ОСНОВІ КАОЛІНІТУ}

\section{А.І. Бондарєва, В.Н. Тобілко, Ю.М. Холодько, Б.Ю. Корнілович, Н.А. Загороднюк}

В даній роботі встановлено основні фізико-хімічні особливості видалення арсенатів із забруднених вод з використанням стабілізованого нанорозмірного заліза. Стабілізацію виконували на неорганічній матриці каолініту. За допомогою фізико-хімічних методів дослідження (рентгенофазовий аналіз, метод низькотемпературної адсорбції-десорбції азоту) вивчено структуру адсорбентів. Показано, що ефективність вилучення арсенат-іонів залежить від масового співвідношення нанопорошку заліза і каолініту, а ступінь очищення вод не залежить від $\mathrm{pH}$ водного середовища в широкому діапазоні. Виконано аналіз процесів кінетики сорбції арсенат-іонів зразками стабілізованого нанорозмірного заліза за допомогою кінетичних моделей адсорбції псевдо-першого та псевдо-другого порядків. Встановлено, що вилучення арсену залізовмісними композитами на основі каолініту відбувається досить швидко. Кінетична залежність сорбціï As(V) одержаними залізовмісними матеріалами краще описується моделлю псевдо-другого порядку, що вказує на високу спорідненість арсенатів з поверхнею залізовмісного нанокомпозиту. Встановлено, що одержані матеріали проявляють значно кращу сорбційну здатність щодо іонів арсену(V) у порівнянні з природними силікатами. Ізотерми сорбції арсену(V) модифікованим каолінітом добре описуються і рівнянням Фрейндліха, і Ленгмюра. Показано, що сорбенти на основі стабілізованого нанорозмірного заліза ефективно вилучають токсичні іони арсену із забруднених вод.

Ключові слова: каолініт, нанорозмірне нульвалентне залізо, нанокомпозитні сорбенти, арсен, очищення води, адсорбція.

\section{EFFICIENT REMOVAL OF ARSENIC(V) FROM WATER USING IRON-CONTAINING NANOCOMPOSITES BASED ON KAOLINITE}

\section{A.I. Bondarieva *, V.Yu. Tobilko, Yu.M. Kholodko, B.Yu. Kornilovych, N.A. Zahorodniuk}

National Technical University of Ukraine «Igor Sikorsky Kyiv Polytechnic Institute», Kyiv, Ukraine

\section{* e-mail: a.i.bondarieva@gmail.com}

We studied the main physicochemical features of removing of arsenate from contaminated waters utilizing stabilized nanoscale iron. An inorganic kaolinite matrix was used for stabilization. The structure of adsorbents was studied using some physicochemical methods (X-ray powder diffraction and the lowtemperature $\mathrm{N}_{2}$ adsorption-desorption method). It was found that the efficiency of the removal of $\operatorname{arsenic}(\mathrm{V})$ ions depends on the weight ratio of iron nanopowder to kaolinite, whereas it does not depend on the $\mathrm{pH}$ of the water systems in a wide range. Kinetics data were analyzed using pseudo-first-order and pseudo-secondorder models. It was stated that the removal of arsenic by ironcontaining composites based on kaolinite occurs relatively rapid. The adsorption kinetic was appropriately described by the pseudosecond-order model, indicating the high affinity of arsenates with the surface of the iron-containing nanocomposite. The results demonstrated that the obtained materials have a much higher sorption capacity to As(V) ions than natural silicates. The Langmuir and Freundlich isotherm equations provided good fittings for the experimental sorption data. It was shown that the sorbents based on stabilized nanoscale iron effectively remove toxic arsenic ions from contaminated water.

Keywords: kaolinite; nanoscale zero-valent iron; nanocomposite sorbents; arsenic; water treatment; adsorption.

\section{REFERENCES}

1. Villaescusa I, Bollinger JC. Arsenic in drinking water: sources, occurrence and health effects (a review). Rev Environ Sci Biotechnol. 2008; 7: 307-323. doi: 10.1007/s11157-008-9138-7.

2. Kapaj S, Peterson H, Liber K, Bhattacharya P. Human health effects from chronic arsenic poisoning-a review. $J$ Environ Sci Health A. 2006; 41(10): 2399-2428.

doi: 10.1080/10934520600873571.

3. Adeloju SB, Khan S, Patti AF. Arsenic contamination of groundwater and its implications for drinking water quality and human health in under-developed countries and remote communities - a review. Appl Sci. 2021; 11(4): 1926-1950.

doi: 10.3390/app11041926.

4. Akter KF, Owens G, Davey DE, Naidu R. Arsenic speciation and toxicity in biological systems. In: Ware GW, Albert LA, Crosby DG, de Voogt P, Hutzinger O, Knaak JB, et al. (editors). Rev Environ Contam Toxicol. 2005; 184: 97-149.

doi: 10.1007/0-387-27565-7_3.

5. Bolisetty S, Peydayesh M, Mezzenga R. Sustainable technologies for water purification from heavy metals: review and analysis. Chem Soc Rev. 2019; 48: 463-487.

doi: 10.1039/C8CS00493E.

6. Kurniawan TA, Chan GYS, Lo WH, Babel S. Comparisons of low-cost adsorbents for treating wastewaters laden with heavy metals. Sci Total Environ. 2006; 366: 409-426. doi: 10.1016/j.scitotenv.2005.10.001.

7. Joseph L, Jun BM, Flora JRV, Park CM, Yoon Y. Removal of heavy metals from water sources in the developing world using low-cost materials: a review. Chemosphere. 2019; 229: 142-159. doi: 10.1016/j.chemosphere.2019.04.198.

8. Nicomel NR, Leus K, Folens K, van der Voort P, Laing GD. Technologies for arsenic removal from water: current status and future perspectives. Int J Environ Res Public Health. 2016; 13(1): 62. doi: 10.3390/ijerph13010062.

9. Li L, Hu J, Shi X, Fan M, Luo J, Wei X. Nanoscale zero-valent metals: a review of synthesis, characterization, and applications to environmental remediation. Environ Sci Pollut Res. 2016; 23: 17880-17900. doi: 10.1007/s11356-016-6626-0.

10. Zou Y, Wang X, Khan A, Wang P, Liu Y, Alsaedi A, et al. Environmental remediation and application of nanoscale zero-valent iron and its composites for the removal of heavy metal ions: a review. Environ Sci Technol. 2016; 50: 7290-7304. doi: 10.1021/acs.est.6b01897.

11. Kuila U, Prasad M. Specific surface area and poresize distribution in clays and shales. Geophys Prospect. 2013; 61: 341-362. doi: 10.1111/1365-2478.12028.

12. Tobilko VYu, Kornilovych BYu. Synthesis and sorption properties of composite materials based on nanoscale $\mathrm{Fe}^{0}$. East Eur J Enterprise Technol. 2015; 4(5): 22-27.

doi: 10.15587/1729-4061.2015.46580.

13. Wu C, Tu J, Liu W, Zhang J, Chu S, Lu G, et al. The double influence mechanism of $\mathrm{pH}$ on arsenic removal by nano zero valent iron: electrostatic interactions and the corrosion of $\mathrm{Fe}^{0}$. Environ Sci Nano. 2017; 4: 1544-1552.

doi: 10.1039/C7EN00240H.

14. Bhowmick S, Chakraborty S, Mondal P, van Renterghem W, van den Berghe S, Roman-Ross G, et al Montmorillonite-supported nanoscale zero-valent iron for removal of arsenic from aqueous solution: kinetics and mechanism. Chem Eng J. 2014; 243: 14-23. doi: 10.1016/j.cej.2013.12.049. 